\title{
The Role of Subak and Competence of Farmers in Maintaining the Welfare of Garlic Farmers
}

\author{
Krisna Heryanda ${ }^{1, *}$ Ni Made Dwi Ariani Mayasari ${ }^{1}$ Wayan Bagia ${ }^{1}$
}

\author{
Gede Putu Agus Jana Susila ${ }^{1}$
}

\begin{abstract}
${ }^{1}$ Department of Management, Universitas Pendidikan Ganesha,Singaraja, Indonesia
*Corresponding author. Email: krisna.heryanda@undiksha.ac.id
\end{abstract}

\begin{abstract}
The contribution of the agricultural sector is highest compared to other sectors in Buleleng district, but the level of welfare of garlic farmers is still low. There are still many farmers who work off-farm to support their families. This study examined the role of subak as a traditional institution in Bali in the welfare of garlic farmers in Buleleng Regency, and reviewed the influence of farmer competence in improving their welfare. The results of the study found that both variables, namely subak and farmer competence, had an effect on the welfare of garlic farmers in Buleleng district. The role of subak in overcoming problems faced by farmers, and the ability of subak to overcome problems that occur among farmers was able to increase farmer productivity which lead to an increase in farmers' income. Meanwhile, the competence of farmers in the adoption of information technology must be continued to be improved to assist the production process and post-harvest marketing of garlic.
\end{abstract}

Keywords: Competence, Garlic, Subak, Welfare.

\section{INTRODUCTION}

The contribution of the agricultural sector to development in several parts of Indonesia is quite high. One of them is Buleleng Regency, which is located in the north of the island of Bali. Most of the development in Bali relies on the tourism sector. However, some areas such as Buleleng Regency are not able to develop the tourism sector optimally so that the contribution of the agricultural sector in Buleleng Regency is only 17-18 percent while the contribution of the agricultural sector is above 20 percent (BPS Buleleng, 2020). Although the contribution of the agricultural sector is higher, the welfare level of farmers in Buleleng Regency is still categorized as low in terms of income, health, education, and housing conditions [1].

One of the interesting aspects of the agricultural sector in Buleleng district is horticultural agriculture, especially garlic. In 1980 to 1990 Buleleng Regency became the center of garlic farming. However, the high cost of production and the entry of cheaper imported garlic caused many farmers in Buleleng district to leave garlic farming. Judging from the amount of garlic production, Buleleng Regency has the potential to re-develop garlic farming.

The welfare level of garlic farmers in Buleleng Regency is not so high. This is because the high production costs that must be incurred cause the difference in profits obtained by farmers to be lower. This is exacerbated by the pandemic conditions that hit causing the demand for local garlic to decrease. During a pandemic, assistance from the government and agricultural institutions such as subak is urgently needed to participate in overcoming the welfare problems of garlic farmers in Buleleng Regency. In addition, the competence of farmers in dealing with pandemics in addition to other problems such as climate and marketing plays a role in maintaining the welfare of farmers [2].

Several subak in Buleleng Regency have started to take part in planting garlic. But in its development, garlic production in Buleleng Regency has decreased. The entry of imported garlic on a large scale makes it difficult for local garlic to compete the price. The price of imported garlic is lower than local garlic as a result of high production costs. This causes garlic farmers in Buleleng Regency switch to farming other promising crops.

In 2018, Bank Indonesia (BI) representatives from Bali carried out the Bank Indonesia Social Program (PSBI) by providing assistance to garlic farmers in Subak Manik Pertiwi, Wanagiri village, Buleleng Regency to develop their garlic production. This program was carried out to provide assistance in the form of seeds, agricultural equipment, and counseling to farmers in collaboration with the Buleleng Regency Agriculture Office. The result of this program was the first garlic harvest in September 2018 where one hectare of land produced 7.8 tons of garlic [3][4] 
After successfully carrying out the program, Bank Indonesia (BI) representatives from Bali and the Buleleng Regency government began to develop several Subak that have the potential to produce garlic. The area of land that would be developed for garlic farming from the 4 Subak was 50 hectares. Looking at data from the Central Statistics Agency in 2019, Buleleng Regency produced 438 tons of garlic. This means that the development of garlic has not been optimal. Garlic planting period takes $90-120$ days ( 3 to 4 months). If the land area is 50 hectares, and per hectare can produce 7.8 tons, where in a year the farmer plants 2 crops, the farmer should be able to produce 780 tons every year. This result (780 tons/year) is still far from the requirement of the regional (Bali Province) garlic needs of 1,127 tons/month and still has to rely on imports [5].

The role of farmer groups such as Subak is very influential on the performance of farming businesses. In some ways, such as the application of religious rituals, meetings between members, social relations with traditional villages and the application of regulations in Subak affect the success of agriculture in the Subak area [6], but the authority of subak is still not optimal. This is because the application of regulations in Subak is still not explicitly implemented [7]. The influence of the outside elements of Subak, both from business circles, speculators and brokers, is very high on the sustainability of Subak's agricultural land and infrastructure. This is often the case for fertile Subak located in coastal areas, where the demand for land for housing development, private villas, and other buildings are increasing. Krama Subak tends to ignore Subak regulations due to the influence of tourism which prioritizes material life over spiritual life.

The role of Subak is to serve the interests of all the interests of its member farmers so that togetherness and harmony are achieved in the irrigation system [8]. However, in reality there are often conflicts between members that are difficult for Subak to resolve. They are conflicts in the distribution of irrigation channels due to water scarcity, conflicts in irrigation development such as the construction of new irrigation channels, conversion of agricultural land to other sectors such as property, as well as violations of the planting schedule [9]. Some of these conflicts greatly disrupt agricultural productivity, and affect decreasing in agricultural production.

Some problems are also difficult to overcome by Subak who develops garlic farming in Buleleng Regency. As obtained in Subak Paitan, Pakisan Village, Kubuaddan District, the problem of water distribution due to differences in cropping patterns makes it difficult for farmers to work on agricultural land that is far from water sources. Farmers who cultivate agricultural land far from water sources must follow the cropping pattern of farmers close to water sources. There are often differences of opinion about the plants that will be developed in their land at the beginning of the growing season. This situation should be solved by subak as a forum for farmers' aspirations. But in reality there are often conflicts of interest that lead to unilateral decisions that are considered less profitable for other farmers.

In addition to external factors, the role of Subak, it is undeniable that the role of farmer competence also greatly affects the productivity of agricultural activities. Human Resources (HR) who have competence in their field will greatly help the success of the activities carried out [10]. Judging from their educational background, farmers generally have low education. This is because agriculture is synonymous with "dirty" work. Besides being identical with 'dirty' work, the reluctance to work as a farmer is due to the fact that there are more uncertainties in working as a farmer. As a result of the absence of guarantees for the welfare of life, more people with low education work as farmers.

Work as a farmer actually requires qualified competence so that the results obtained are optimal. Some agricultural jobs even require skills such as crop development, pesticide used, plant maintenance, and marketing agricultural products. These quite diverse jobs must be accompanied by adequate competencies [11]. Without adequate competence from farmers, it will be difficult to achieve optimal productivity and increase welfare. The low level of competence of farmers cannot be separated from the assumption of "dirty" jobs attached to farmers. Most of the farmer's jobs are filled by people who have low levels of education. So far, farmers use farming techniques that have been passed down from previous generations [12]. This makes agricultural production sometimes does not develop and even decreases due to farming techniques that are still the same as before, coupled with increasingly narrow agricultural land.

The competence of garlic farmers in Buleleng Regency is still relatively low. Most of the education level of farmers is still at the elementary school level. Although the experience is quite high, this causes the adoption of technology to be less effective. The use of high-tech tools has not been able to be applied as in agriculture in developed countries. In addition, the condition of farmers who are dominated by ages above 45 years makes it increasingly difficult to adopt technology and apply more modern agricultural methods [13].

From the explanation above, this paper will reveal how the role of subak and competence can maintain the welfare of garlic farmers in Buleleng Regency

\section{METHOD}

This study used quantitative research methods. Quantitative research according to [14] is a research method based on the philosophy of positivism, used to 
examine certain populations or samples, data collection using research instruments, data analysis is quantitative/statistical, with the aim of testing predetermined hypotheses. The data from the questionnaire was analyzed by multiple regression analysis assisted by SPSS ver software. 26 for windows.

The population used were farmers from 4 subak who developed garlic farming in Buleleng Regency. The 4 subak were Paitan subak in Pakisan village with 86 farmers, lanyahan subak in Bonthihing village with 112 farmers, manik pertiwi subak in Wanagiri village with 91 farmers and Munduk subak in Munduk village with 64 farmers. The total population were 353 farmers. By the large population of respondents, the data collection was carried out by sampling technique using the slovin $\mathrm{n}=\mathrm{N}$ $(1+\mathrm{N}$ e2) formula with a 90 percent confidence level. The calculation results got the number of respondents in this study is 78 people (rounded up).

Data collection techniques was questionnaires. Questionnaires were distributed to farmers who were selected as samples. In addition, to make it easier during a pandemic like this, some farmers were sent a google form to make it easier and avoid interacting directly. The data analysis technique was carried out by testing the validity and reliability of the research instrument. After that, data analysis was carried out using multiple linear regression to answer the research hypothesis.

\section{RESULTS AND DISCUSSION}

The validity and reliability of the research instrument can be seen in the following table.

Table 1. Validity and Reliability of The Research

\begin{tabular}{|l|l|l|l|l|}
\hline & $\begin{array}{l}\text { Cronbach's } \\
\text { Alpha }\end{array}$ & rho_A & $\begin{array}{l}\text { Composite } \\
\text { Reliability }\end{array}$ & $\begin{array}{l}\text { Average } \\
\text { Variance } \\
\text { Extracted } \\
\text { (AVE) }\end{array}$ \\
\hline $\begin{array}{l}\text { Farmer } \\
\text { Competence_- } \\
\text { X2) }\end{array}$ & 0,775 & 0,816 & 0,869 & 0,692 \\
\hline $\begin{array}{l}\text { The Role Of } \\
\text { Subak_(X1) }\end{array}$ & 0,797 & 0,804 & 0,868 & 0,622 \\
\hline $\begin{array}{l}\text { Wekk- } \\
\text { Being_(Y) }\end{array}$ & 0,820 & 0,824 & 0,892 & 0,735 \\
\hline
\end{tabular}

Judging from the value of Cronbach's Alpha, all variables, both $\mathrm{X}_{1}$ (Role of Subak), $\mathrm{X}_{2}$ (Farmers' Competence), and $\mathrm{Y}$ (Welfare) all have values > 0.7, which means that all research variables were reliable. The Average Variance Extracted (AVE) value of all variables is $>0.5$, which means that all research variables are valid. The results of the multicollinearity test stated that all indicators of the research variables had a VIF value of $<0.5$, which means they were free from multicollinearity.
The results of multiple linear regression analysis obtained the following image.

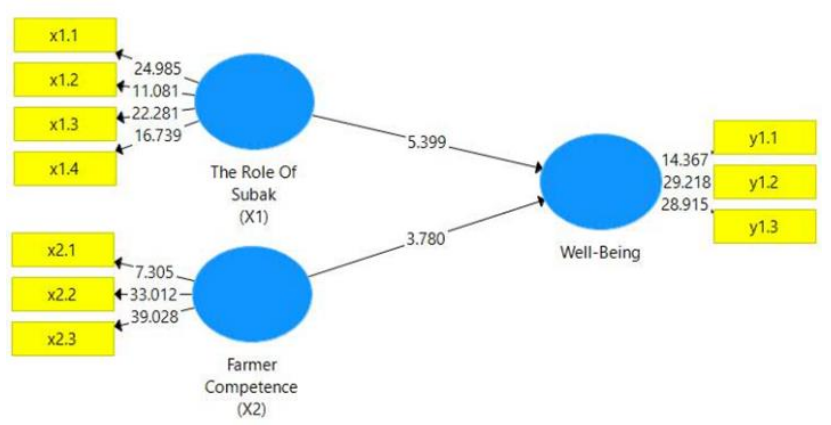

Figure 1 The Results of Multiple Linear Regression

The partial effect of each independent variable can be seen in the following table.

Table 2. The Partial Effect of Each Independent Variable

\begin{tabular}{|l|l|l|l|l|l|}
\hline & $\begin{array}{c}\text { Original } \\
\text { Sample } \\
(\mathrm{O})\end{array}$ & $\begin{array}{c}\text { Sample } \\
\text { Mean } \\
(\mathrm{M})\end{array}$ & $\begin{array}{c}\text { Standart } \\
\text { Deviation } \\
\text { (STDEV) }\end{array}$ & $\begin{array}{c}\text { T } \\
\text { Statistic } \\
\text { (O/ } \\
\text { STDEV) }\end{array}$ & P Values \\
\hline $\begin{array}{l}\text { Farmer } \\
\text { Competence_(0,382 } \\
\text { X2)->Well- } \\
\text { Being_(Y) }\end{array}$ & 0,383 & 0,101 & 3,780 & 0,000 \\
\hline $\begin{array}{l}\text { The Role Of } \\
\text { Subak_(X1) } \\
>\text { Well- } \\
\text { Being_(Y) }\end{array}$ & 0,509 & 0,506 & 0,094 & 5,399 & 0,000 \\
\hline
\end{tabular}

From the table above, it can be seen that the role of subak variable has a regression coefficient of 0.509 with a t-value of 5.399. The significance value is $0.000<0.05$, which means that the role of Subak has a positive and significant impact on the welfare of garlic farmers in Buleleng Regency. While the coefficient value of the influence of farmer competence on farmer welfare is 0.382 with a t-value of 3.780 . The significance value is $0.000<0.05$, which means that the competence of farmers has a positive and significant effect on the welfare of garlic farmers in Buleleng Regency. Simultaneous test with an F-value of 80.607 and a significance value of $0.000<0.05$, which means that the role of subak and the competence of farmers have a significant effect on the welfare of garlic farmers in Buleleng Regency.

The role of subak in agriculture has been proven to be able to increase agricultural yields and farmers' welfare. The results showed that the role of subak was able to improve the welfare of farmers. The existence of subak is able to make farming methods more regular so that the results obtained are maximized [9]. So far, the role of subak was not only in terms of distributing irrigation 
water. Subak also plays a role in mobilizing available resources so that they are able to complete heavy work in agriculture [15]. In addition, subak plays a role in solving problems that occur among farmers [16]. Problems that are quickly resolved cause farmers to quickly produce which has an impact on increasing agricultural production. In addition to production, several subaks in Bali are able to develop their agriculture into agrotourism that has economic value for farmers [17].

The role of Subak in garlic farming in Buleleng Regency was felt to be quite helpful in production. It was easier for farmers to communicate with other farmers through subak. The difficulties faced by farmers such as pests and nurseries can be assisted by subak so that the quality and quantity of garlic production can be maintained. Subak is also an intermediary for farmers and buyers of garlic so that the selling price of garlic can benefit farmers. The existence of this important subak becomes the hope of garlic farmers in the future, so that the welfare they get from agriculture will increase.

Competence of farmers is needed in planning, implementation, and post-harvest. The ability of farmers to overcome the problems they face will have an impact on agricultural production and farmers' income [18]. It is in line with The higher the ability of farmers to run their business, the higher their agricultural performance which has an impact on improving the welfare of farmers [19]. Farmers' knowledge about the agriculture they do and also the ability to predict future conditions will determine the results of agricultural production [20].

The competence of garlic farmers in Buleleng Regency in producing was quite good. It's just that the weaknesses in access to capital and marketing are still quite minimal. This cannot be separated from the education that most farmers have up to high school. In addition, the age of farmers who were more than 50 years causes the technology adoption to be slow. The adoption of information technology was felt to be very minimal in its use in garlic farming. Farmers still rely on information from agricultural extension workers and other farmers. This caused problems faced by farmers to be slowly resolved so that it interfered with their production. Several attempts have been made to overcome this, but there are still obstacles in the field that cannot be resolved quickly.

\section{CONCLUSION}

The togetherness-oriented Subak can be a forum to solve the difficulties faced by farmers so that the welfare of farmers during this pandemic can be maintained. The ability of farmers can encourage farmers to be more creative in dealing with various situations. High farmer competence can make farmers more creative during this pandemic so that welfare can continue to be improved
Subak is faster in helping the problems faced by farmers so that it does not interfere with the production process carried out by farmers. In addition, subak is expected to be able to maintain the area of production land so that agricultural land is not getting narrower. Increasing the competence of farmers can be done by increasing the adoption of information technology to support agriculture. The adoption of information technology will make farmers receive information more quickly. The information itself as well as fertilizers, seeds, pesticides, and selling prices.

\section{REFERENCES}

[1] B. K. Buleleng, Indikator Kesejahteraan Rakyat Kabupaten Buleleng 2019/2020, vol. Singaraja: BPS Kabupaten Buleleng, 2020.

[2] M. I. Bahua, "Managerial competencies in agriculture," Eur. Res. Stud. J., vol. 21, no. 2, pp. 623-629, 2018.

[3] Y. Surtiani and L. Budiati, "Evaluasi Rehabilitasi Hutan dan Lahan ( RHL ) di Daerah Aliran Sungai ( DAS ) Juwana pada Kawasan Gunung Muria Kabupaten Pati," J. Pembang. Wil. Kota, vol. 11, no. 1, p. 117, 2015, doi: 10.14710/pwk.v11i1.8662.

[4] D. P. K. Buleleng, "Program Sosial Bank Indonesia (PSBI) dan Panen Perdana Bawang Putih," https://distan.bulelengkab.go.id/foto/programsosial-bank-indonesia-psbi-dan-panen-perdanabawang-putih-95, 2018.

[5] B. Bisnis, "Stok Bawang Putih Impor di Bali Cukup Sampai April,"

https://bali.bisnis.com/read/20200204/538/119715 4/stok-bawang-putih-impor-di-bali-cukup-sampaiapril, 2020.

[6] C. Kardi, "Upaya peningkatan daya saing Subak dalam pengembangan pertanian berkelanjutan dan pariwisata kerakyatan di Kabupaten Buleleng," J. Agrimeta, vol. 2, no. 3, pp. 1-18, 2012.

[7] D. Roth, "The Subak in Diaspora: Balinese Farmers and the Subak in South Sulawesi," Hum. Ecol., vol. 39, no. 1, pp. 55-68, 2011, doi: 10.1007/s10745010-9374-7.

[8] W. Windia, "Sustainability Of Subak Irrigation System In Bali (Experience of Bali Island)," Semin. Hist. Irrig. East. Asia, pp. 1-9, 2010.

[9] W. Widiatmaka, "Subak Sebagai Benteng Konservasi Peradaban Bali," 2019. [Online]. Available:

https://www.researchgate.net/publication/3359701 57. 
[10] I. Manyamsari and Mujiburrahmad, "Karakteristik Petani Dan Hubungannya Dengan Kompetensi Petani Lahan Sempit (Kasus: Di Desa Sinar Sari Kecamatan Dramaga Kab. Bogor Jawa Barat)," Agrisep, vol. 15, no. 2, pp. 58-74, 2014, doi: 10.24815/agrisep.v15i2.2099.

[11] V. Vathanophas, "Competency Requirements for Effective Job Performance in Thai Public Sector," Contemp. Manag. Res., vol. 3, no. 1, p. 45, 2006, doi: $10.7903 / \mathrm{cmr} .49$.

[12] V. Jufitra, "Perkembangan Penyuluhan Pertanian Dalam Mendukung Pertumbuhan Pertanian Di Indonesia," Responsive, vol. 1, no. 3, pp. 1-8, 2019.

[13] R. Palan, Competency Management: Teknik Mengimplementasikan Manajemen SDM Berbasis Kompetensi untuk Meningkatan Daya Saing Organisasi." Cetakan 2. Jakarta: Jakarta: PPM, 2008.

[14] Sugiyono, Metode Penelitian Kombinasi (Mix Methods). Bandung: Bandung; Alfabeta, 2015.

[15] I. Aryawan, W. Windia, and P. Wijayanti, "Peranan Subak dalam Aktivitas Pertanian Padi Sawah (Kasus di Subak Dalem, Kecamatan Kerambitan, Kabupaten Tabanan)," E-Journal Agribisnis dan Agrowisata (Journal Agribus. Agritourism), vol. 2, no. 1, pp. 1-11, 2013.

[16] I. Lanya, N. N. Subadiyasa, and G. P. Ratna Adi, "Impact of spatial plan on the conversion of Subak rice fields and food security, in Badung and Gianyar Regencies, Bali Province," IOP Conf. Ser. Earth Environ. Sci., vol. 149, no. 1, 2018, doi: 10.1088/1755-1315/149/1/012003.

[17] I. W. Budiasa, B. I. Setiawan, H. Kato, N. Sekino, and J. Kubota, "The Role Of The Subak System And Tourism On Land Use Changes Within The Saba Watershed, Northern Bali, Indonesia," J. Int. Soc. Southeast Asian Agric. Sci., vol. 21, no. 2, pp. 3147, 2015.

[18] R. S. Damihartini and A. Jahi, "Hubungan Karakteristik Petani Dengan Kompetensi Agribisnis Pada Usahatani Sayuran Di Kabupaten Kediri Jawa Timur," J. Penyul., vol. 1, no. 1, 2005, doi: 10.25015/penyuluhan.v1i1.2097.

[19] A. Paranata, A. Daeng, and B. S. Wijimulawiani, "Mengurai Model Kesejahteraan Petani," vol. 5, no. 1, pp. 90-102, 2012, doi: 10.15294/jejak.v5i1.4633.

[20] U. Anifa and M. Y. Darsyah, "Analysis of Onion Farming Income in Central jakarta," Prosiding Seminar Nasional Mahasiswa Unimus (Vol., vol. 1, no. February, 2018. 